\title{
INVESTIGATION OF LATVIAN LANGUAGE PROGRAM MANAGEMENT MODELS IN MAJOR WORLDWIDE UNIVERSITIES
}

\author{
Yan Lu \\ University of Latvia, Latvia
}

\begin{abstract}
Compared with some European countries and America, Latvian language teaching is relatively new practice in China. Since the launch of the first Latvian language program at Beijing Foreign Studies University (BFSU) in 2010, three management models have been implemented and evaluated. For almost 10 years, approximately 130 students have been involved in Latvian language learning, either in elective courses or in bachelor degree programs. Positive results have been observed, but problems still exist. Lack of experience, limited staff and materials lead to unsystematic teaching practice and make it difficult to fulfil the aims. To look for solutions, one effective way is to learn from others' experience. This investigation took "Latvian language program management model in tertiary level" as subject, used the methods of document analysis, semi-structured interview and observation to conclude and compare the program management models in the main universities which teach Latvian language. During the period of March, 2018 to January, 2019, 4 teachers and 3 students from 5 universities were interviewed. Besides, although Latvian language teaching in Japan is not organized in tertiary level, considering the similarity of learning style, the teaching practice in Japan was also included in the investigation. Data analysis compared the key factors in the 6 cases and presented mainly three management models, which offered good examples for teaching practice in China. The case in America especially showed an effective solution to the problem in the Discipline-directional module at BFSU. Furthermore, it was also observed that the program management in different universities is quite enclosed, and the programs seldom have multilateral cooperation. It also recommended to promote cooperation among the programs in different countries, in order to maximize the effectiveness of teaching resources.
\end{abstract}

Keywords: Latvian as foreign language, program management model, tertiary level. 


\section{Introduction}

1. Management of the Latvian Language Programs in China

The development of cooperation between China and EU promotes the EU official languages studies in China, including Latvian language. In 2010, Beijing Foreign Studies University (BFSU) initiated the first Latvian language program. But due to lack of local teachers and teaching materials specific for Chinese learners, the Latvian Language Teaching-research Office at BFSU currently manages this program in form of elective course, which is instructed by teachers from Latvia and accessible to all students in bachelor's studies. In this phase, BFSU also trains local teachers and develops teaching materials in cooperation with the University of Latvia and the Latvian Language Agency. According to the plan, the first group of 4-year bachelor students will be enrolled in 2020. The bachelor program consists of 8 semesters, among which, in the previous 4 semesters main attention is paid to language skills and proficiency. During the last 4 semesters students are led to improve language proficiency, to intensively get general knowledge about Latvia and Europe, as well as to start study in a specific discipline with Latvian language. Within the 8 semesters, students spend 2 semesters in Latvia as an exchange student.

After the initiation of "China-CEEC" Cooperation, more universities in China have interest to start Latvian language program. In 2015, Beijing International Studies University (BISU) began to enrol students in two management models: one is " $3+4$ " Model, which includes 3-year high school and 4-year bachelor's studies; the other one is regular 4-year bachelor's program. Programs are administrated by local staff and all lectures are instructed by teachers from Latvia.

Until now, approximately 130 students in the two universities have been involved in Latvian language learning. Positive results have been observed in three management models, but problems also exist. The aims of Latvian language program management are to recruit a well-structured group of teachers with professional skills and distinct research interests, to guarantee students opportunity to fulfil Latvian language proficiency and necessary competence, to support students do basic studies in one discipline with Latvian language, furthermore to prepare them for labour market or further study which is related to Latvia. However, lack of experience, limited staff and materials lead to unsystematic teaching practice and make it difficult to fulfil all the aims.

The aim of this research is to investigate and analyse the management models of the Latvian language program in other universities worldwide, to find solutions to the existing problems in the practice in China, and to get prepared for the first bachelor students' enrolment at BFSU. 
2. The Overview of Teaching Latvian as Foreign Language Worldwide

Latvian is one of the two living languages with official status, which belong to the Baltic branch of the Indo-European language family. It retains many archaic features of the Proto-Indo-European language; therefore, it has high linguistic value and attracts linguists' research interest. In Europe, some universities, such as University of Stockholm and University of Vilnius, started to teach Latvian in 1970s or even earlier (Šalme, Žìgure, 2008, 9). However, due to the historical situation in Latvia, Latvian language learning and research were just limited in the academia of some specialists.

In 1990s, after Latvian restoration of independence, a booming period of Latvian language teaching was observed in Europe. Since then, more than 20 universities have managed Latvian language teaching mainly in three models: specific academic program, interdisciplinary course in some certain programs and elective course (Šalme, Žìgure, 2008, 5). Moreover, teaching practice started in another continent. In 1993, University of Washington organized the Baltic Studies Summer Institute and began to teach Latvian at multiple levels in autumn in 1994.

At the beginning of the 21st century, especially since Latvia became the EU member, situation has greatly changed. On one hand, the status of Latvian is strengthened as one official language in EU; on the other hand, the mobility in higher education in EU also promoted the language learning. Summer school, distance teaching and self-learning materials are in request as supplement to traditional classroom teaching. In this phase, Teaching Latvian as a Foreign Language (TLFL) became a subject in educational science, which is parallel with Teaching Latvian as the Mother Tongue and Teaching Latvian as a Second Language (Šalme, Žìgure, 2008, 5).

Since the new sub-discipline was defined, academia has paid more attention to this field. A number of researches have been done to present TLFL theory and practice (Šalme, 2008, 2011; Horiguchi, 2010; Šalme, Auziņa, 2016; Lapinska, 2016; Laizāne, 2016, 2017, 2018; Lauze, Laivenice, 2018; Grīnberga, 2018), and more teaching materials for foreigners, even specific for learners in some certain countries have been published with the support of the Latvian Language Agency. However, the focus of these achievements is mainly on language teaching and acquisition; the management of the Latvian language program in the institutions is seldom discussed.

In the last ten years, it is observed that some Latvian language programs in Europe are in shrink: the number of the enrolled students decreases, and some programs even temporarily are suspended. In contrast, a new tendency appears in East Asia. Besides the situation mentioned above in China, practice of Latvian language teaching in Japan is also worthy to be 
discussed, although it is not organized as regular program in university. In 2007, Tokyo Foreign Studies University started to arrange Latvian language courses in summer school. Besides, from 2007 and 2009 respectively, learners who are interested in the language have the opportunity to learn it in the Latvia Embassy in Tokyo and Consulate Section in Osaka (Horiguchi, 2010).

\section{Methodology and Materials}

The investigation was mainly implemented by semi-structured interview. Interviews were conducted during the period from March, 2018 to January, 2019. The participants include 5 teachers and 3 students. Details are as follows: 3 master students from the University of Warsaw (UW-PL), 1 teacher from the Stockholm University (SU), 1 teacher from the Vilnius University (VU), 1 teacher from the University of Tartu (UT) and 1 teacher from the Rìga Stradiňš University. Among which, the teacher from the Rìga Stradiņš University in 2014 conducted a semi-structured interview with her colleague, who was working at the University of Washington (UW-USA), and she reported the results, which were required in this investigation. Although the Latvian language courses in Japan are not organized in tertiary level, taking into consideration the similarity of learning style between Chinese and Japanese, one Japanese teacher, who is promoting Latvian language study, was also invited to the interview. The questions were about the key components in the program management process, and its details are presented in the next section.

Besides, document analysis and observation were employed as complementary methods. The analysed documents included program information on the homepage, syllabi, textbooks and teaching materials, reports of the Latvian Language Agency, etc. Observation on the general environment was made in the University of Stockholm, University of Vilnius and University of Tartu.

\section{Results and Discussions}

The main results, which were generated in the investigation, are listed in Table 1.

In all the 5 universities, Latvian language programs are subprograms under Baltic-related programs, among which, the 4 programs in Europe are more focus on philology, while the program in the University of Washington is related to regional studies. According to the type of courses offered by the Latvian language subprograms, the management models in the 5 universities can be divided into 3 categories. In the first model, the 
Table 1. The key components of program management in the investigated institutions

\begin{tabular}{|c|c|c|c|c|c|c|}
\hline & UW-PL & SU & VU & UT & UW-USA & Japan \\
\hline Faculty & $\begin{array}{c}\text { Department } \\
\text { of General } \\
\text { Linguistics, } \\
\text { East Asian } \\
\text { Comparative } \\
\text { Linguistics } \\
\text { and Baltic } \\
\text { Studies }\end{array}$ & $\begin{array}{l}\text { Department } \\
\text { of Slavic } \\
\text { and Baltic } \\
\text { Studies, } \\
\text { Finnish, } \\
\text { Dutch and } \\
\text { German }\end{array}$ & $\begin{array}{l}\text { Faculty of } \\
\text { Philology }\end{array}$ & $\begin{array}{c}\text { Faculty of } \\
\text { Arts and } \\
\text { Humanities }\end{array}$ & $\begin{array}{c}\text { Scandinavian } \\
\text { Department }\end{array}$ & $\begin{array}{c}\text { (Embassy } \\
\text { in } \\
\text { Tokyo) }\end{array}$ \\
\hline $\begin{array}{l}\text { General } \\
\text { program }\end{array}$ & $\begin{array}{c}\text { Baltic } \\
\text { Philology }\end{array}$ & $\begin{array}{c}\text { Baltic } \\
\text { Languages }\end{array}$ & $\begin{array}{l}\text { Lithuanian } \\
\text { Philology } \\
\text { and Latvian } \\
\text { Language }\end{array}$ & $\begin{array}{c}\text { Languages } \\
\text { of the Baltic } \\
\text { Region }\end{array}$ & Baltic Studies & -- \\
\hline $\begin{array}{l}\text { Year of } \\
\text { initiate }\end{array}$ & 1995 & 1972 & 1999 & 1997 & 1994 & 2007 \\
\hline $\begin{array}{l}\text { Needs } \\
\text { analysis }\end{array}$ & $\begin{array}{c}\text { research and } \\
\text { professional } \\
\text { needs }\end{array}$ & $\begin{array}{l}\text { research } \\
\text { and } \\
\text { personal } \\
\text { interest }\end{array}$ & $\begin{array}{l}\text { research } \\
\text { and } \\
\text { professional } \\
\text { needs }\end{array}$ & $\begin{array}{c}\text { research, } \\
\text { professional } \\
\text { needs and } \\
\text { personal } \\
\text { interest }\end{array}$ & $\begin{array}{c}\text { research and } \\
\text { personal } \\
\text { interest }\end{array}$ & $\begin{array}{l}\text { Personal } \\
\text { interest }\end{array}$ \\
\hline Circle & BA, MA & $\begin{array}{l}\text { BA, MA, } \\
\text { PhD }\end{array}$ & $\begin{array}{l}\text { BA, MA, } \\
\text { PhD }\end{array}$ & $\begin{array}{l}\text { BA, MA, } \\
\text { PhD }\end{array}$ & BA, MA, PhD & -- \\
\hline $\begin{array}{l}\begin{array}{l}\text { Type of } \\
\text { course }\end{array} \\
\end{array}$ & compulsory & elective & directional & elective & directional & -- \\
\hline $\begin{array}{l}\text { Hours of } \\
\text { language } \\
\text { course in the } \\
1^{\text {st }} \text { semester } \\
\text { (per week) }\end{array}$ & 5 & 4 & $\begin{array}{c}4 \text { (old) } \\
10 \text { (new) }\end{array}$ & 4 & 5 & 2 \\
\hline $\begin{array}{l}\begin{array}{l}\text { Number of } \\
\text { semesters }\end{array} \\
\end{array}$ & 4 & $2-4$ & $\begin{array}{c}2-4 \text { (old) } \\
7 \text { (new) }\end{array}$ & 1 & 4 & -- \\
\hline $\begin{array}{l}\text { Number of } \\
\text { staff }\end{array}$ & 3 (2 local) & 3 & 3 (local) & 1 & 2 (1 local) & 1(local) \\
\hline $\begin{array}{l}\text { Localized } \\
\text { textbook }\end{array}$ & no & yes & yes & yes & yes & yes \\
\hline $\begin{array}{l}\text { Exchange } \\
\text { study }\end{array}$ & $0.5-1$ year & -- & 0.5 year & $0.5-1$ year & -- & -- \\
\hline $\begin{array}{l}\text { Language } \\
\text { practice }\end{array}$ & compulsory & -- & -- & -- & -- & -- \\
\hline $\begin{array}{l}\text { Required } \\
\text { language } \\
\text { proficiency }\end{array}$ & $\begin{array}{l}\text { B2 (BA) } \\
\text { C1 (MA) }\end{array}$ & -- & B1-B2 (BA) & $\mathrm{A} 1-\mathrm{A} 2$ & -- & -- \\
\hline
\end{tabular}


Latvian language subprogram organizes elective language courses, which are accessible to students in all three circles at university level. The main aim of the courses is to offer basic Latvian language knowledge and to support students to fulfil their interest or competence in research, work or personal life. The University of Stockholm and the University of Tartu employ this model in practice. It is similar to the present model at BFSU. In the second model, the Latvian language subprogram is in the same direction with the general program. Students can choose the subprogram as their programme of study, finish the relevant courses and get diploma in this field. Examples are the University of Vilnius and the University of Washington. The program of Lithuanian Philology in VU offers two directions: Latvian language and Polish language. VU now is updating the curriculum and the new one notably increases the hours for Latvian language and culture knowledge. The Baltic Studies Program in the University of Washington is managed in Scandinavian Department and offers three course lines, that is Latvian, Lithuanian and Estonian. The curriculum includes language courses, Baltic core courses and courses with Baltic content. In the third model, the Latvian language courses are compulsory to all students in the program. This is the management model of the program of Baltic Philology in the University of Warsaw. This model has the highest requirement to students' language proficiency; it clearly defines the language proficiency level, which should be achieved in bachelor and master studies, as well as requires students to do certain amount of language practice.

The above-mentioned results and analysis show that in these universities, the main role of Latvian language courses is somewhat a complement for students to do their studies in the general program: the requirement to language proficiency is not quite strict and explicit, except in the University of Warsaw; the study hours for Latvian language are not many, usually 4-5 hours, except the new curriculum in Vilnius University; and other courses in the general program are instructed in mother tongue or English. However, the idea of the language program management in China significantly varies. This can be observed in Table 2 .

Table 2. The distribution of study hours in the curriculum at BFSU (per week)

\begin{tabular}{|l|c|c|c|}
\hline & Language proficiency & $\begin{array}{c}\text { Related } \\
\text { knowledge }\end{array}$ & $\begin{array}{c}\text { Discipline- } \\
\text { direction }\end{array}$ \\
\hline & \multicolumn{2}{|c|}{ Compulsory module } & Elective module \\
\hline the $1^{\text {st }}$ year & 24 & 4 & -- \\
\hline the $2^{\text {nd }}$ year & 24 & 4 & -- \\
\hline the $3^{\text {rd }}$ year & 12 & 8 & 6 \\
\hline
\end{tabular}




\begin{tabular}{|l|l|l|l|}
\hline the $4^{\text {th }}$ year & 6 & 10 & 6 \\
\hline
\end{tabular}

Probably due to the degree of difference between the target and native languages, as well as distinct language teaching philosophy and tradition, the Latvian language program in China is managed as a general program and language proficiency is the foundation in the curriculum. The study in lower grades is to prepare students with intermediate language skills and related knowledge; in upper grades is to enhance the competence for language use and to lead students to do elementary research in a specific direction, as well as to encourage them to write thesis in Latvian. After the bachelor's studies, students can use Latvian language to work or to do further study.

This model guarantees students with good foreign language competence, and is proved in practice in such as English, German, Russian language programs, which own professional teams of staff and are relatively mature both in theory and practice. However, the Less Commonly Taught Languages programs, among which one is the Latvian language program, at present are very difficult to achieve the same results. Firstly, the whole curriculum is heavy workload for the limited number of teaching staff, especially the courses in Discipline-direction module are quite hard for novice teachers to instruct in Latvian. Secondly, compared with English, German, etc., Latvian language is relatively "small", if the Latvian language program just emphasizes the target language and country, it also restricts students' opportunities to do studies in a broader context. The model adopted in the University of Washington offers an effective example to solve the problems. BFSU has all the language programs in the Baltic Sea Region and Scandinavia, and all the programs are more or less facing the problems mentioned above. Thus, these programs can consider to make a joint program and to integrate resources in the general program with separate subprograms.

The practice in Japan pointed out the role of exotic culture in motivating learners and cultural events in promoting language learning. Latvian Embassy in Japan regularly organizes speech contests with reward of trip to Latvia, offers opportunities for learners to learn Latvian culture in a deeper level. The local teacher also organizes a choir to teach the Latvian language in singing. Some successful cases already emerged, who are now rather active in Latvian folklore area.

It was also observed the importance of localization in the language program management, especially the local teaching staff. The local teachers are more familiar with local situation and culture. They can manage the program more suitable to the needs of learners and society, seek and combine more resources, develop local learning materials and make the 
program more stable and long-term. The practice in the University of Warsaw and the University of Vilnius proves this point. The best examples yet are in Japan and the USA. Although the geographic distance is very far, with the efforts of local managers and teachers, the programs are constantly in development.

Besides, it worths mentioning that the program management in different universities is quite enclosed. Except the students' conference "Bridges in the Baltics" and teachers' training in the Latvian Language Agency, all the programs seldom have multilateral communication or cooperation. Latvian language program is relatively "small" in foreign language teaching worldwide. This situation calls for more mobility and integration, such as international seminars or joint research projects, in order to improve the sub-discipline TLFL in a sound way.

\section{Conclusions}

Although ideas and models in the Latvian language program management vary in different universities worldwide, the practice in other countries still provide good examples to solve the problems existing in China.

The model, which combines several language subprograms in the University of Washington, shows a most possible way to solve the problem in Discipline-directional Module at BFSU. It not only breaks the barriers among the language programs, integrates the existing teaching resources to maximise the utility, but also provides students more comprehensive background to do their studies.

Cultural events in Japan show the role of exotic culture in motivating learners to learn a "small" language, which has also been proved in the previous teaching practice in China. Thus, emphasis on culture should be continued in further management, in order to transfer students' short-term enthusiasm into long-term interest.

Localisation is another emphasis in program management, especially training local teachers, who have qualified language proficiency and knowledge, eagerness to pursue this career, as well as competence to do team work with colleagues from Latvia.

Besides, the development of TLFL can not be achieved in one program or one country. Since the scale of each program is small, in the context of globalisation, the enclosure should be broken, and cooperative model should be formed to discuss common topics on TLFL, which involves both teachers from Latvia and local teachers. 


\section{References}

Grīnberga, I. (2018). The Art of Teaching Latvian as a Heritage Language: Research and Practice. In: Laiveniece, D. (Eds.) Problems of and Perspectives on Language Acquisition (pp. 146-154). Newcastle upon Tyne: Cambridge Scholars Publishing.

Horiguchi, D. (2010). Kopības sajūta valodas klasē - piemērs no latviešu valodas apguvējiem japāniem [Togetherness in a Language Classroom - Example from Japanese Learners of the Latvian Language]. Valodu apguve: problèmas un perspektīva [Language Acquisition: Problems and Perspective]. 7, 28-37.

Laizāne, I. (2016). Lietišķās valodniecības ideju ietekme uz latviešu valodas kā svešvalodas attīstību [Influence of Applied Linguistics Ideas on the Development of Teaching Latvian as a Foreign Language]. Via scientiarum. 56-65.

Laizāne, I. (2017). Acquisition of Latvian as a Foreign Language in Latvia: Development and Trends. Rural environment. Education. Personality. 116-120.

Laizāne, I. (2018). Acquisition of Latvian as a Foreign Language in the Baltic States. In: Laiveniece, D. (Eds.) Problems of and Perspectives on Language Acquisition (pp. 134-145). Newcastle upon Tyne: Cambridge Scholars Publishing.

Lapinska, I. (2016). Latviešu valodas apguve ārvalstu augstskolās [Latvian Language Acquisition at Universities Abroad]. In: Lauze, L., Kḷava, G. , Vītola, I. (Eds.) Valodas situācija Latvijā 2010-2015 [Language Situation in Latvia 2010-2015] (pp. 157-172). Rīga: LVA.

Lauze, L., Laiveniece, D. (2018). Use of Intermediary Language and Translating in Acquiring Latvian as a Foreign Language. In: Laiveniece, D. (Eds.) Problems of and Perspectives on Language Acquisition (pp. 155-166). Newcastle upon Tyne: Cambridge Scholars Publishing.

Šalme, A. (2011). Latviešu valodas kā svešvalodas apguves pamatjautājumi [Basic Issues in Acquisition of Latvian as a Foreign Language]. Rīga: LVA.

Šalme, A., Auziña, I. (2016). Latviešu valodas prasmes limmeñi [Levels of Latvian Language Proficiency]. Rīga: LVA.

Šalme, A., Žīgure, V., Vaivode, L, Helviga, I. (2008). Latviešu valodas kā svešvalodas apguve Eiropas augstskolās [Acquisition of Latvian as a Foreign Language at European Institutions of Higher Education]. Rīga: Valsts valodas aǵentūra [National Language Agency]. 